\section{NFUD 2020}

Nytt år og nye muligheter for å videreutvikle din ultralydkompetanse, formidle kasuistikker eller spennende forskningsresultat, og ikke minst, oppleve Eurosonkongressen i Bergen i juni.

\section{NFUDs informasjonskanaler}

\section{Flaggermusen}

I NFUD ønsker vi å promotere norsk ultralydforskning. Her i foreningens faste spalte, Flaggermusen, i Ultraschall in der Medizin, har vi muligheten til dette. Hvis noen av våre medlemmer ønsker å presentere pågående eller nylig avsluttede doktorgradsprosjekter, oppfordrer vi til å ta kontakt med flaggermusansvarlig i styret (flaggermusen@nfud.no).

\section{Hjemmesider}

På våre hjemmesider nfud.no finner du spennende nytt fra ultralydmiljøet i Norge. Linker viser vei til faglig material som medlemmer har tilgang til, og i tillegg kan man på hjemmesidene finne oversikt over relevante kurs, spennende forskning og månedens kasuistikk. Vil du bidra med kasuistikker eller har tips om spennende forskningsartikler, ta kontakt med webansvarlig (webansvarlig@nfud.no). Skriv til oss både om du selv er forfatter eller kjenner til relevant forskning innen ultralyd, enten det handler om teknologien i seg selv, obstetrikk/gynekologi, revmatologi, muskelog skjelett, gastroenterologi, allmennmedisin, akuttmedisin, kardiologi eller noe annet interessant!

Følg ellers med på NFUDs aktiviteter på Facebook (Norsk forening for ultralyddiagnostikk - NFUD) og Twitter (@UltralydNorge).

\section{Program for Euroson 2020}

Sjekk det spennende programmet for Euroson 2020 i Bergen 11.-13. juni! Detaljert program med titler og foredragsholdere er tilgjengelig på euroson2020.org. Parallellsesjon 1 er i hovedsak SonoScandinavia sitt kurs med mye hands-on trening. Kongressdeltakere kan følge SonoScandinavia sine forelesninger, men det er egen påmelding og kursavgift for hands-on delen av kurset.

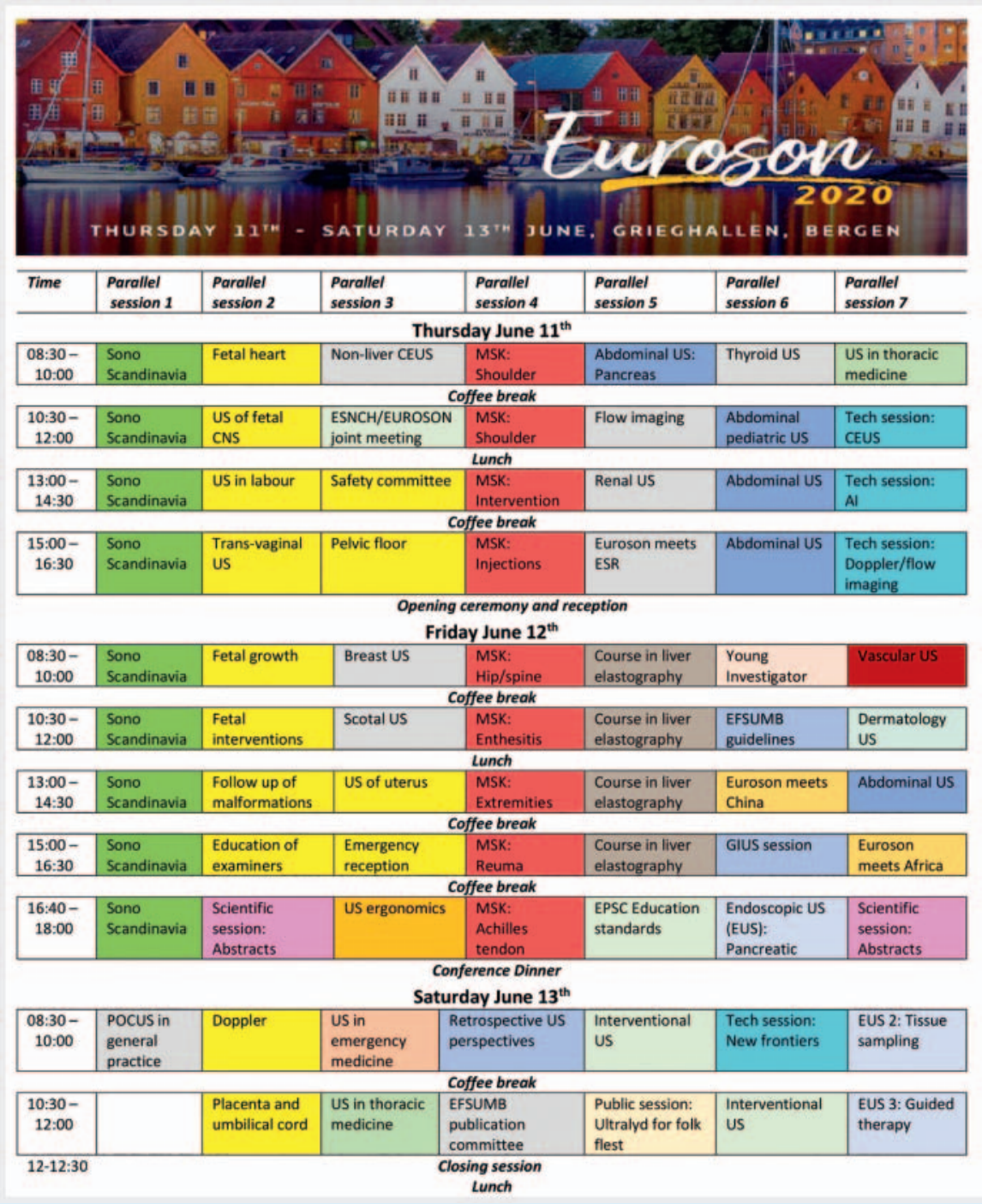

Se euroson2020.org for påmelding og mer informasjon. I tillegg til parallellsesjonene vist her, vil det også være postersesjoner med premiering av beste poster, et stort område for utstillere, og ikke minst, egne studentsesjoner med POCUS og hands-on trening.

\section{Vi sees på Euroson 2020!}

